\title{
GIS-based gully erosion susceptibility modeling, adapting bivariate statistical method and AHP approach in Gombe town and environs Northeast Nigeria
}

\author{
Ogbonnaya Igwe, Ugwuoke Ikechukwu John º, Onwuka Solomon and Ozioko Obinna
}

\begin{abstract}
Gully erosion is a major environmental problem in Gombe town, a large area of land is becoming unsuitable for human settlement, hence the need for a gully erosion susceptibility map of the study area. To generate a gully inventory map, a detailed field exercise was carried out, during this investigation one hundred gullies were identified and studied extensively within the study area of about $550 \mathrm{~km}^{2}$. In addition to the mapped gullies, Google EarthPro with high-resolution imagery was used to locate the spatial extents of fifty (50) more gullies. Ten gully erosion predisposing factors were carefully selected considering the information obtained from literature, and multiple field survey of the study area, the factors include elevation, slope angle, curvature, aspect, topographic wetness index (TWI), soil texture, geology, drainage buffer, road buffer and landuse. In this study, a GIS-based Frequency Ratio (FR) and Analytical Hierarchy Process (AHP) models were employed to predict areas prone to gully erosion in Gombe town and environs. The result obtained from FR shows that drainage, soil texture, and slope have the highest correlation with gully occurrence, while the AHP model revealed that drainage buffer, soil texture, geology have a high correlation with the formation of a gully. Gully erosion susceptibility maps (GESM) were produced and reclassified into very high, high, moderate, and low zones. The overall accuracies of both models were tested utilizing area under the curve (AUC) values and gully density distribution.FR and AHP model have AUC values of 0.73 and 0.72 respectively, the outcome indicates that both models have high prediction accuracy. The gully erosion density distribution values revealed that gullies are concentrated in the very high susceptibility class and it decreases towards the low class, therefore the GESM produced using these models in this study area is reliable and can be used for land management and future planning.
\end{abstract}

Keywords: GESM, GIS, Prediction, Frequency ratio, Analytical hierarchy process

\section{Introduction}

One of the factors that endanger water and soil is soil erosion (Magliulo 2012). The major cause of land degradation around the world is soil erosion by gully erosion (Nampak et al. 2018; Rizeei et al. 2016). Gully erosion is defined as a deep channel that is formed by concentrated water flow, which in the process removes surface soils and materials (Kirkby and Bracken 2009).

* Correspondence: jiyke64@gmail.com

Department of Geology, University of Nigeria, Nsukka, Nigeria
The changes in the quantity of moisture content resulting from dry and wet seasons are a major factor contributing to cracks and grooves in clay formations consequently forming rilled erosion and gullies (Torri et al. 2012). Runoff accumulates within these cracks at the first sudden rainfall and consequently, gully develops. Under natural conditions, vegetation helps to hold soil in place and protect it from the direct impact of rainfall thereby controlling run-off. The effect caused by excessive clearing, inappropriate landuse, and 
compaction of the soil caused by grazing is that the soil becomes exposed and unable to absorb excess water, this implies that there becomes an elevated level of Surface run-off that concentrates in drainage lines, making it possible for the occurrence of gullies in susceptible areas, (Ligonja and Shrestha 2015). The threat of gully erosion on the socio-economic development of Gombe state (Fig. 1) includes the destruction of houses, loss of lives, displacement of people, land depreciation, destruction of roads and culverts (Mbaya 2017). To better identify areas prone to gully erosion and realize the mechanism involved it becomes expedient to invent a gully erosion susceptibility map (GESM) (Arabameri et al. 2018). The demarcation of an area into zones of varying susceptibility is made possible by the estimation of the input of each conditioning factor. Several models have been created and employed to analyze both quantitatively and qualitatively, the rate of gully erosion. Lately, researchers have executed statistical and machine learning methods in other to determine the statistical relationship that exists between gully erosion factors and the spatial distribution of gullies (Magliulo 2012). Several researchers have assessed control measures and the effect of gully erosion in Gombe town, but no work has been done to produce a reliable gully erosion susceptibility map (GESM) adapting Frequency Ratio (FR) and Analytical Hierarchy Process (AHP) models. The objective of this research includes: To develop a gully inventory map of the study area, secondly, to produce all relevant thematic maps for the conditioning factors and establish the correlation between predisposing factors and gully occurrence, to apply Frequency Ratio and Analytical Hierarchy Process (AHP) models to produce GESM and finally, to validate the produced susceptibility maps using AUC and gully density distribution.

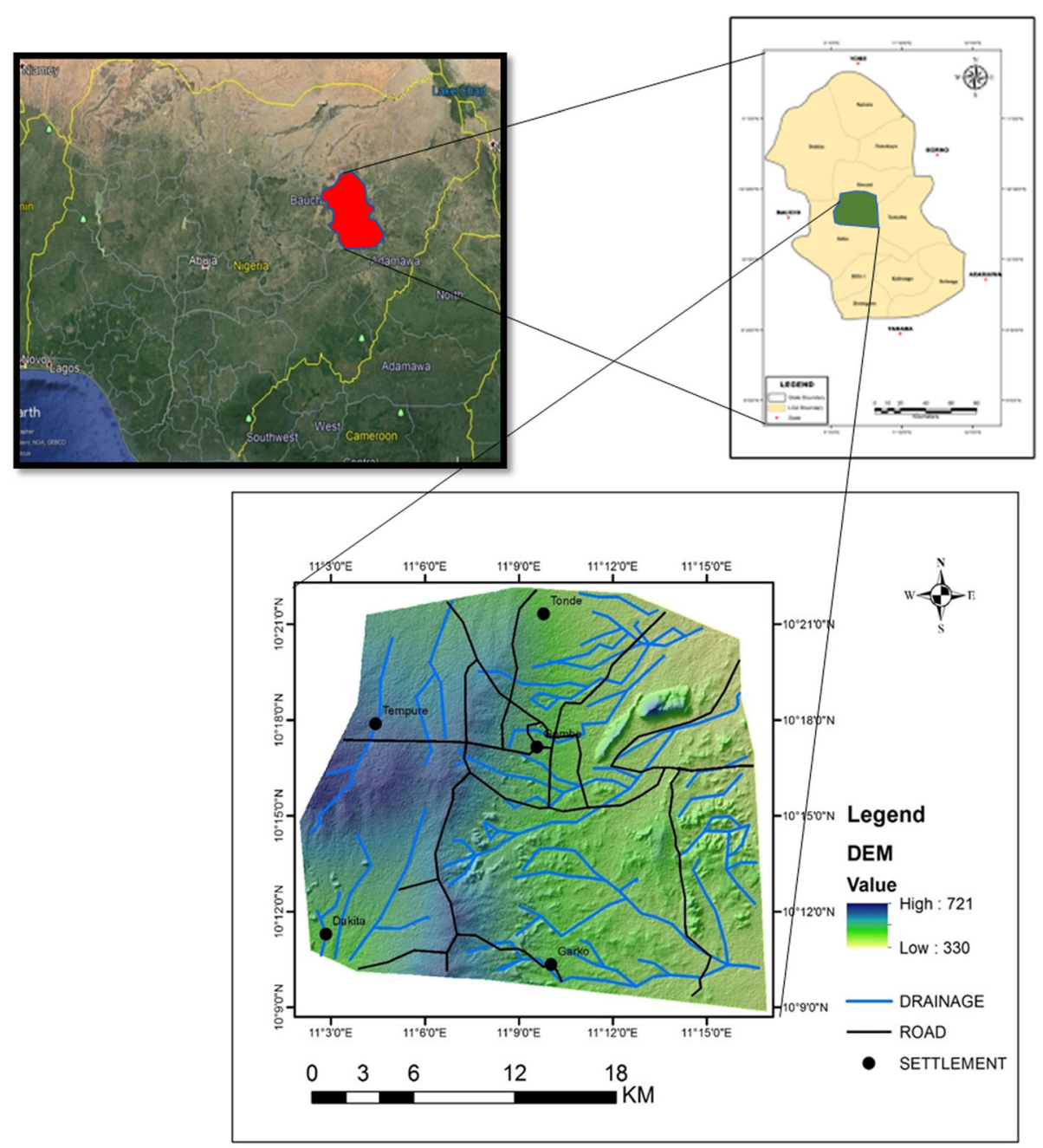

Fig. 1 Geologic map of the study area 


\section{Climate and vegetation}

The area is characterized by wet and dry seasons, having a mean annual rainfall and temperature of $850 \mathrm{~mm}$ and $32{ }^{\circ} \mathrm{C}$ respectively. Rainfall within the study area occurs mostly between June and September. Precipitation is associated with a storm of high intensity, especially in July and August. The vegetation of the Gombe area can be described as Sudan savannah with open grassland and shrubs which dries up during the dry season, the vegetation comprises of scattered shrubs and trees.

\section{Geology}

The study area is located in the north-south trending Gongola basin of the upper Benue Trough, it is underlain by four geologic Formations, they include, Yolde Formation, Pindiga Formation, Gombe Sandstone, and Kerri-Kerri Formation. (Fig. 1) The Yolde Formation is Cenomanian in age, deposited in continental to the marine environment it comprises of sandstone and shale at the base while the top consists of sandstones, shales, and calcareous sandstone (Abubakar et al. 2008). The Cenomanian-Santonian marine Pindiga Formation, consisting of thick marine shale, with some limestone beds toward the base (Zaborski et al. 1997).while the Gombe sandstone is the last cretaceous deposit in the Gongola arm of the Upper Benue trough. It is underlain by the marine Pindiga Formation and overlain by the Kerri-Kerri Formation. The lacustrine to deltaic Gombe Formation consists of well-bedded fine to medium-grained friable, ferruginous sandstone, siltstone, and shale with ironstone (Orazulike 1988). Three major lithofacies characterize this formation, they include the basal transitional portion, bedded facies, and red sandstone facies. At its base, it comprises intercalation of silty shale occasionally, with plant remains (Zaborski et al. 1997). The continental Kerri-Kerri Formation ended sediment deposition in the Upper Benue Trough; it consists of sandstones, siltstones, and shales.

\section{Geomorphology}

The complex geologic crystalline bedrock formed the base on which the relief of Gombe was established. The elevation of the study area is within $330 \mathrm{~m}$ to $721 \mathrm{~m}$ (Fig. 2). The flat-topped to conical hills characterized the landscape; this landscape is the outcome of dissection and stream incision in the area after the deposition of sedimentary formation during the late cretaceous period. Aside from the Gombe hill and Liji hill (Fig. 3.) Gombe town is generally taken to be a flat area (Arabi et al. 2009).

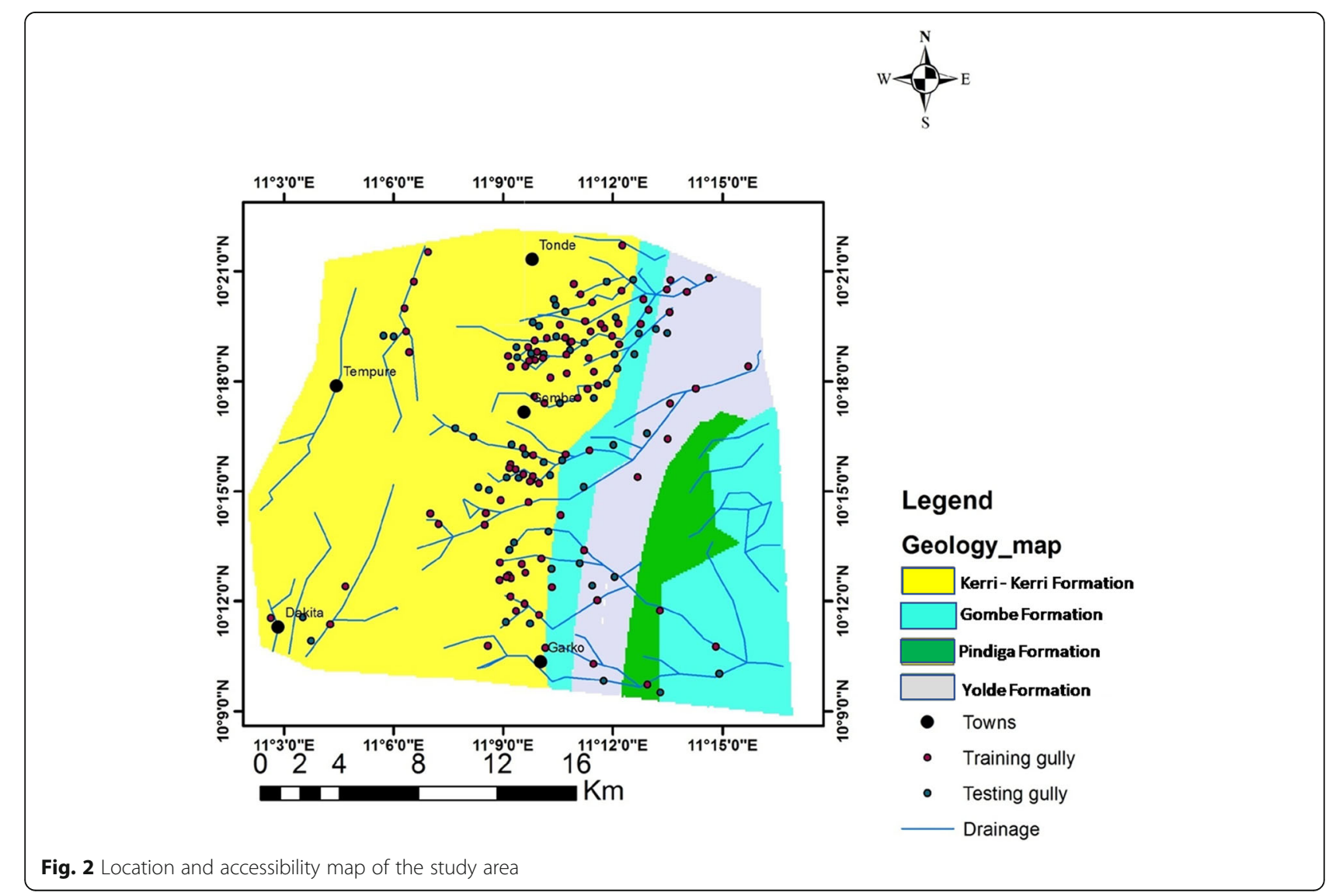




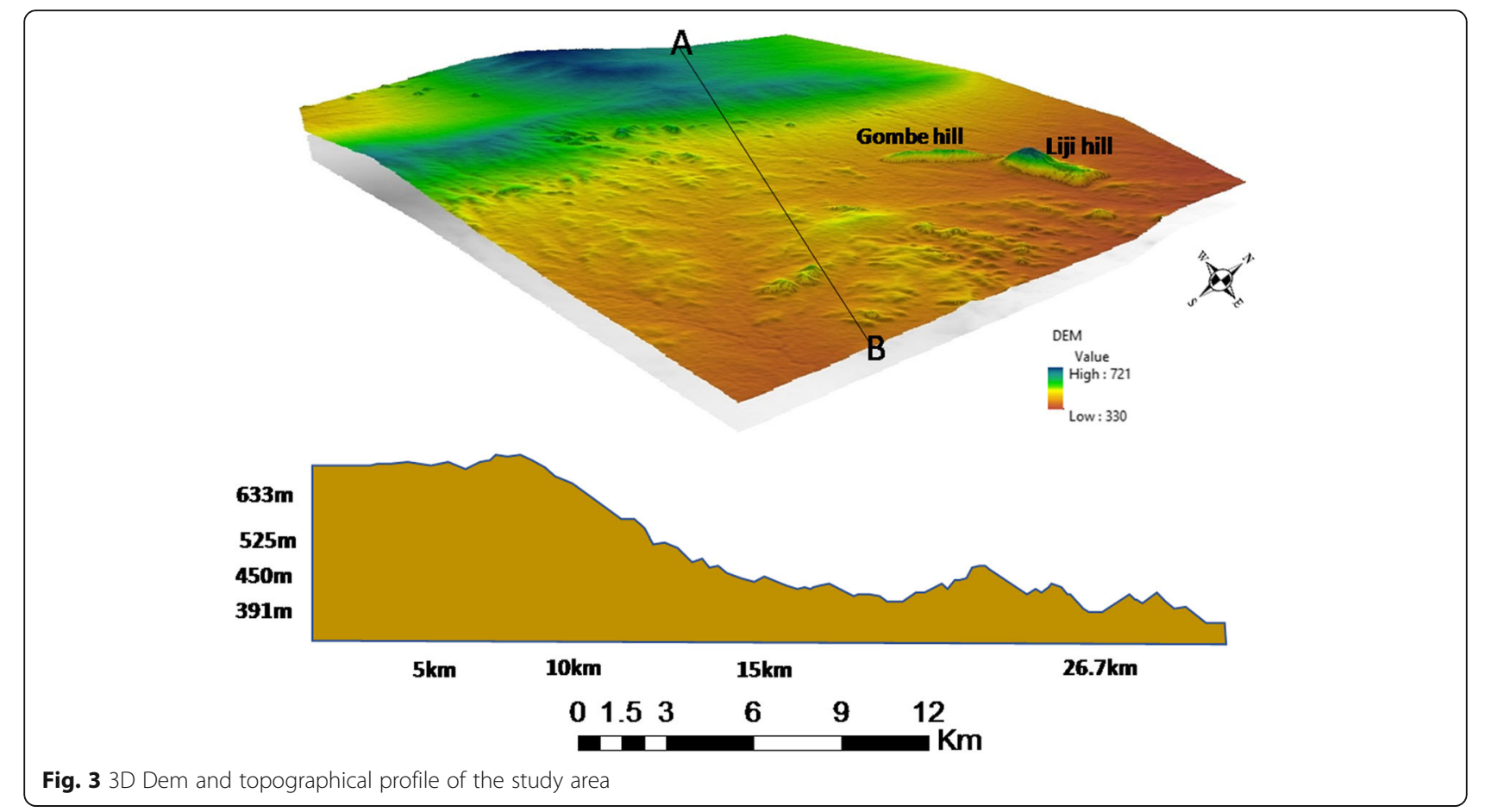

\section{Methodology}

The methodology employed in this research is summarized in the flowchart in Fig. 4. The first approach to this study to generate a reliable gully inventory map was to embark on a detailed field survey. Ten gully erosion predisposing factors were carefully selected considering information obtained from the literature and field survey of the study area. Next was to produce thematic maps corresponding with the chosen conditioning factors. ASTER DEM with a resolution of $30 \mathrm{~m} \times 30 \mathrm{~m}$ was used to extract Topographic related factors such as elevation, slope angle, curvature, aspect, topographic wetness index. The geological map was digitized from a previously existing geological map produced by Nigeria

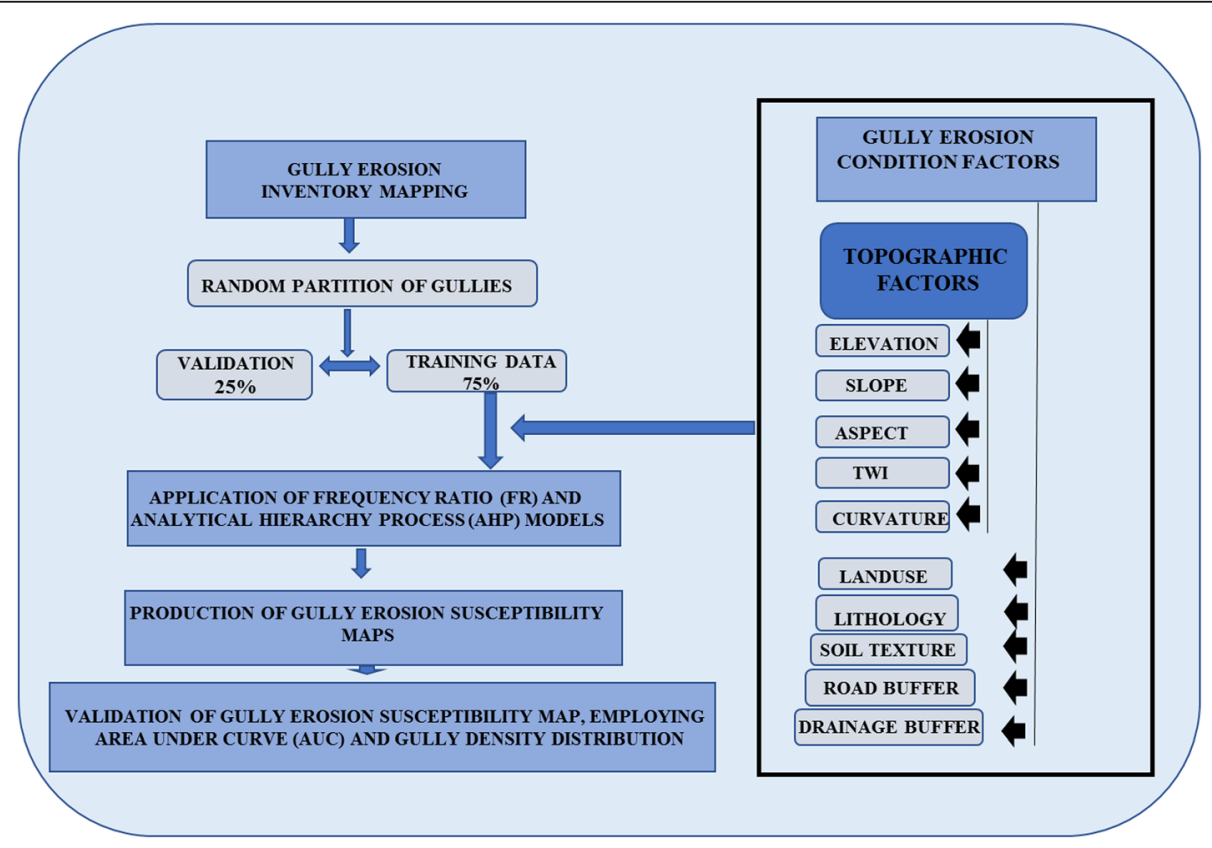

Fig. 4 Methodology flowchart 
Geological Survey Agency (NGSA) while soil map obtained from the Institute for Agricultural Research; Ahmadu Bello University Zaria Nigeria was obtained and digitized to produce the soil texture map of the area. Drainage buffer and road buffer were digitized from Google Earth imagery while Landsat $8^{\text {tw }} 30 \mathrm{~m}$ resolution was employed to produce the landuse map in ArcGIS version 10.4 .

The modeling phase required that all the gully erosion training (75\%) and testing (25\%) data were selected randomly and overlain over all the produced thematic maps in the ArcGIS environment. After the rasterization of all produced thematic maps, in other to ensure uniformity of the areal extent and resolution, the thematic maps were masked with Digital Elevation Model (DEM) of a $30 \mathrm{~m} \times 30 \mathrm{~m}$ grid size. The prediction rate acquired from the Frequency Ratio approach together with the criteria weights from the AHP were subsequently integrated into the ArcGIS raster calculator, at this point each conditioning factor map was multiplied with their respective prediction rates and criteria weights, at the end of these process the susceptibility index map was produced. The Gully Erosion Susceptibility Index Maps generated were reclassified into four zones of different degrees of susceptibility to gully occurrence. To validate the accuracy of the prediction, the area under the curve (AUC) and gully density distribution technique was used. The area of gully erosions in a susceptibility zone was divided by the area of the zone to determine the gully erosion density distribution.

\section{Frequency ratio (FR)}

Frequency ratio (FR) is the ratio of the area where gullies occurred in the study area to the whole study area. For a given factor, it is the ratio of the possibility of gully occurrence to its nonoccurrence (Lee and Talib 2005). The frequency ratio model is a bivariate statistical method (Ouyang et al. 2017) employed for calculating the possible relationship between gully erosion and conditioning factors. It is necessary to have several independent variables that are required to determine the dependent variables (Abedini et al. 2017). According to

$$
F R=(A B) /(C / D)
$$

A represents the number of pixels within gully erosion for each class of geo-environmental factors, and B represents the total number of gullies in the study area, while $\mathrm{C}$ represents the total number of pixels within each class of the predisposing factors, and finally, D represents the total number of pixels in the study area.

The Frequency Ratio correlation value varies between $<1$ to $>1$. When FR value is observed to be less than 1 , it indicates a low correlation between gully location and each class of the predisposing factor, on the other hand, a higher correlation exists if the FR value is observed to be higher than 1 (Poudyal et al. 2010).

\section{Analytic hierarchy process (AHP)}

AHP was introduced by Saaty (1980) and is considered as a multi-criteria and multi-objective method, in this method, weights, which are decisions made are assigned based on the knowledge and experience of an expert. These weights are assigned in a form of pairwise relative comparison (Bathrellos et al. 2017; Papadakis and Karimalis 2017).

In the Analytical Hierarchy Process (AHP) the numerical value for each conditioning factor must be between 1 and 9 in the comparison matrix as represented in (Table 1). In the matrix of this study, the conditioning factors for gully occurrence were organized hierarchically. A numerical value was allocated to each predisposing factor, based on their importance as compared with one another (Saaty 1980). The Eigenvalue $(\lambda \max )$ and the Consistency Ratio (CR) were gotten after calculations were executed using the average of the hierarchically arranged factors according to Saaty (1980), in other to achieve a consistent comparison matrix the Eigenvalue $(\lambda \max )$ and the total number of factors (n) have to be the same.

Mathematically Consistency Index is expressed as.

$$
\mathrm{CI}=\frac{\lambda \max -\mathrm{n}}{n-1}
$$

$\mathrm{CI}$ is the consistency index, $\lambda \max$ is the Eigenvalue, and $\mathrm{n}$ represents the total number of factors being compared. Consistency Ratio (CR) is used to check for the consistency of the comparison matrix.

Table 1 The scale of preference between two factors in AHP (Saaty 1980)

\begin{tabular}{lll}
\hline Preference factor & Degree of preference & Definition \\
\hline $\mathbf{1}$ & Equally & two factors have equal importance to the desired objective \\
$\mathbf{3}$ & Moderately & One factor slightly has more importance than the other to the desired objective \\
$\mathbf{5}$ & Strongly & A factor strongly has higher importance than the other towards achieving the desired objective \\
$\mathbf{7}$ & Very strongly & Here a factor has very strong importance more than the other towards achieving its objective \\
$\mathbf{9}$ & Extremely & One factor is extremely more important than the other toward achieving the desired objective \\
$\mathbf{2 , 4 , 6 , 8}$ & Intermediate & when factor importance is between $1,3,4,7$ and 9
\end{tabular}


Table 2 Random index (Saaty 1980)

\begin{tabular}{lllllllllll}
\hline No. & $\mathbf{1}$ & $\mathbf{2}$ & $\mathbf{3}$ & $\mathbf{4}$ & $\mathbf{5}$ & $\mathbf{6}$ & $\mathbf{7}$ & $\mathbf{8}$ & $\mathbf{9}$ & $\mathbf{1 0}$ \\
\hline CR & 0.00 & 0.00 & 0.58 & 0.90 & 1.12 & 1.24 & 1.32 & 1.41 & 1.45 & 1.49 \\
\hline
\end{tabular}

CR is expressed as follows:

$$
\mathrm{CR}=\frac{\mathrm{CI}}{\mathrm{RI}}
$$

CR represents the Consistency Ratio, CI represents the Consistency Index, and RI is the Random consistency Index of the pairwise comparison matrix. Table 2 shows the Random consistency index. The rule for the consistency index states that a Consistency Ratio (CR) that is equal to or less than 0.1 signifies that the matrix is acceptable; while a ratio of more than 0.1 means that the matrix is not consistent (Saaty 1980). The susceptibility index map was finally generated for the AHP model in the ArcGIS environment integrating the Arc Map raster calculator, the gully susceptibility index map generated was subsequently divided into low, moderate, high, and very high susceptibility zones according to the natural break classification method (Tian et al. 2017).

\section{Gully erosion inventory}

To generate a comprehensive and dependable gully inventory map, as shown in Fig. 5, a detailed field survey was done, (Guzzetti et al. 2002) and more gullies were identified from high-resolution imagery from Google Earth. Figure 6 shows some photographs of some gullies in the study area. Next was the conversion of the gully areas represented as polygon to points and they were also overlain on a hill shade view of the area. Among all the 150 mapped gullies, $75 \%$ (113 gullies) of the mapped gullies in the study area were used for training. The training data was used in the modeling phases for the spatial prediction of gullies susceptible zones in the study area. While 25\% (37 gullies) of the mapped gullies were used as testing data (Chung and Fabbri 2003; Dube et al. 2014) this was utilized in the validation of the gully erosion susceptibility models generated.

\section{Conditioning factors}

Quite a several factors contribute to gully erosion as discussed in the literature (Dube et al. 2014), the occurrence

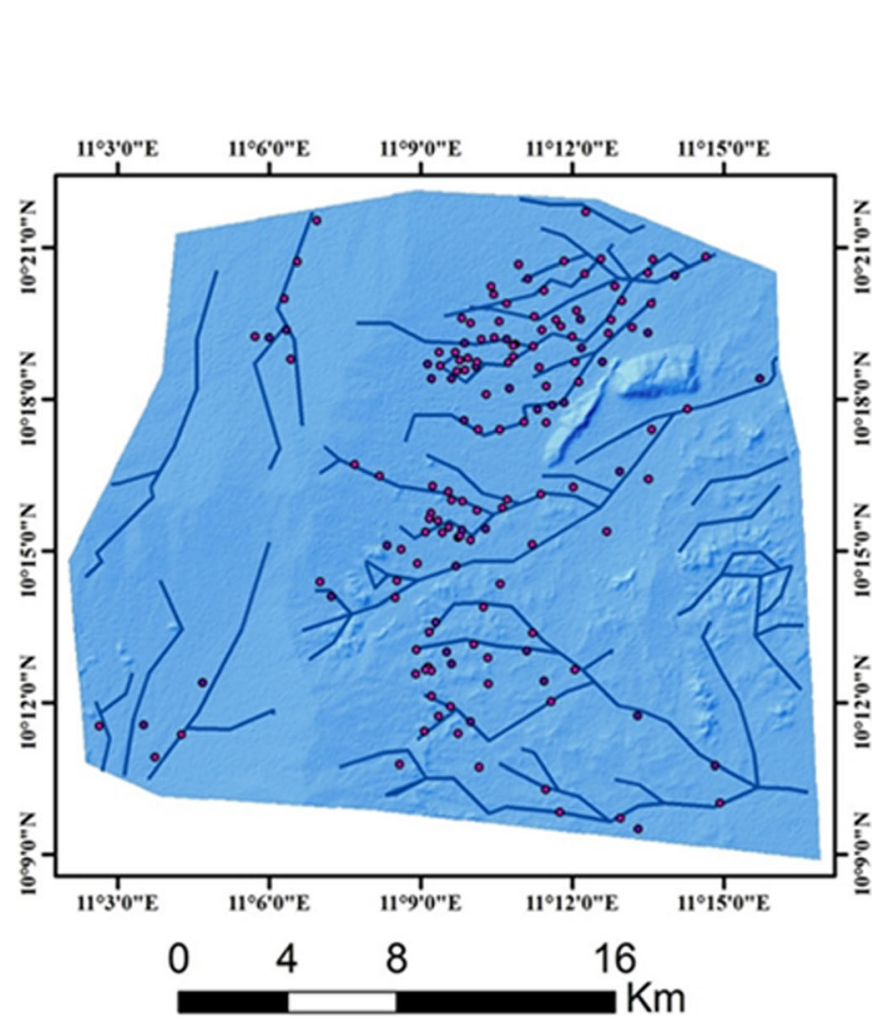

Legend

Hillshade

Value

High : 244

Low : 18

- Drainage

- Training_gully

- Testing_gully

Fig. 5 Gully inventory map is shown as hill shade view of the area 

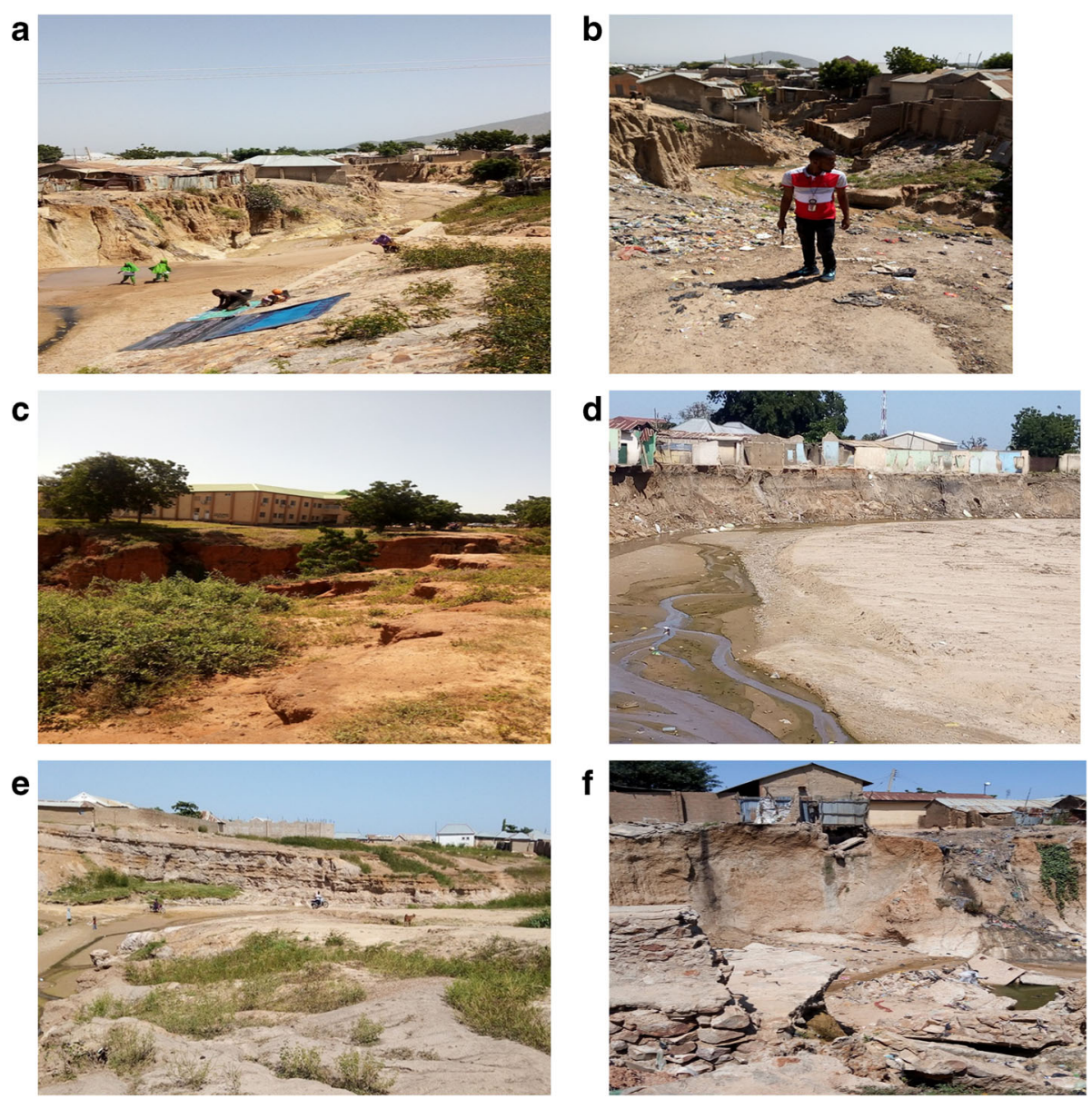

Fig. 6 a-f shows field photograph of some gullies in the study area

of gully erosion and its behavior depends on the following factors: topography characteristics, climate, lithology, soil characteristics, and land use (Poesen et al. 2003; Gutiérrez et al. 2009). The erodibility of the geologic formation in an area and the erosivity of surface runoff determine how susceptible the environment is to the formation of the gully (Conoscenti et al. 2008; Conforti et al. 2011).

\section{Drainage buffer}

The movement of eroded sediments is usually facilitated by drainage, therefore it could be said that gullies are associated with drainage (Conoscenti et al. 2014). The erosive actions in the drainage channels consequently reduce the shear strength of the slope material thereby increasing their chances of failure by sliding (Ozioko and Igwe 2020). The distance from the drainage network was calculated in ArcGIS 10.4.1. Five buffer zones were created within the study area to determine the effect of drainages on gullies occurrence (Fig. 7a), they include $0-0.5 \mathrm{~km}, 0.5-1 \mathrm{~km}, 1-2 \mathrm{~km}, 2-3 \mathrm{~km}, 3-5 \mathrm{~km}$.

\section{Soil texture}

Soil's physical properties are a major contributing factor to runoff, soil infiltration, gully occurrence, and soil resistance to erosion (Xia et al. 2015). The occurrence of subsurface flow and piping is a function of the soil texture, the formation of gullies follows the collapse of the top of these pipes Chaplot et al. 2005). It is expedient that the soil's texture is put into consideration in other to assess gully erosion susceptibility (Conoscenti et al. 2013). Four soil texture types were identified in the study areas (Fig. 7b), they include sandy loam, stony, sandy clay, sandy,

\section{Slope degree}

ASTER DEM was used to obtain the slope information of the area the slope of the area was divided into five cases: 2-4,4-9, 9-16, 16-43 (Fig. 7c). Surface flow accumulation is common in flat areas and consequently initiation the formation of the gully (Rahmati et al. 2015; Ghorbani Nejad et al. 2017). 


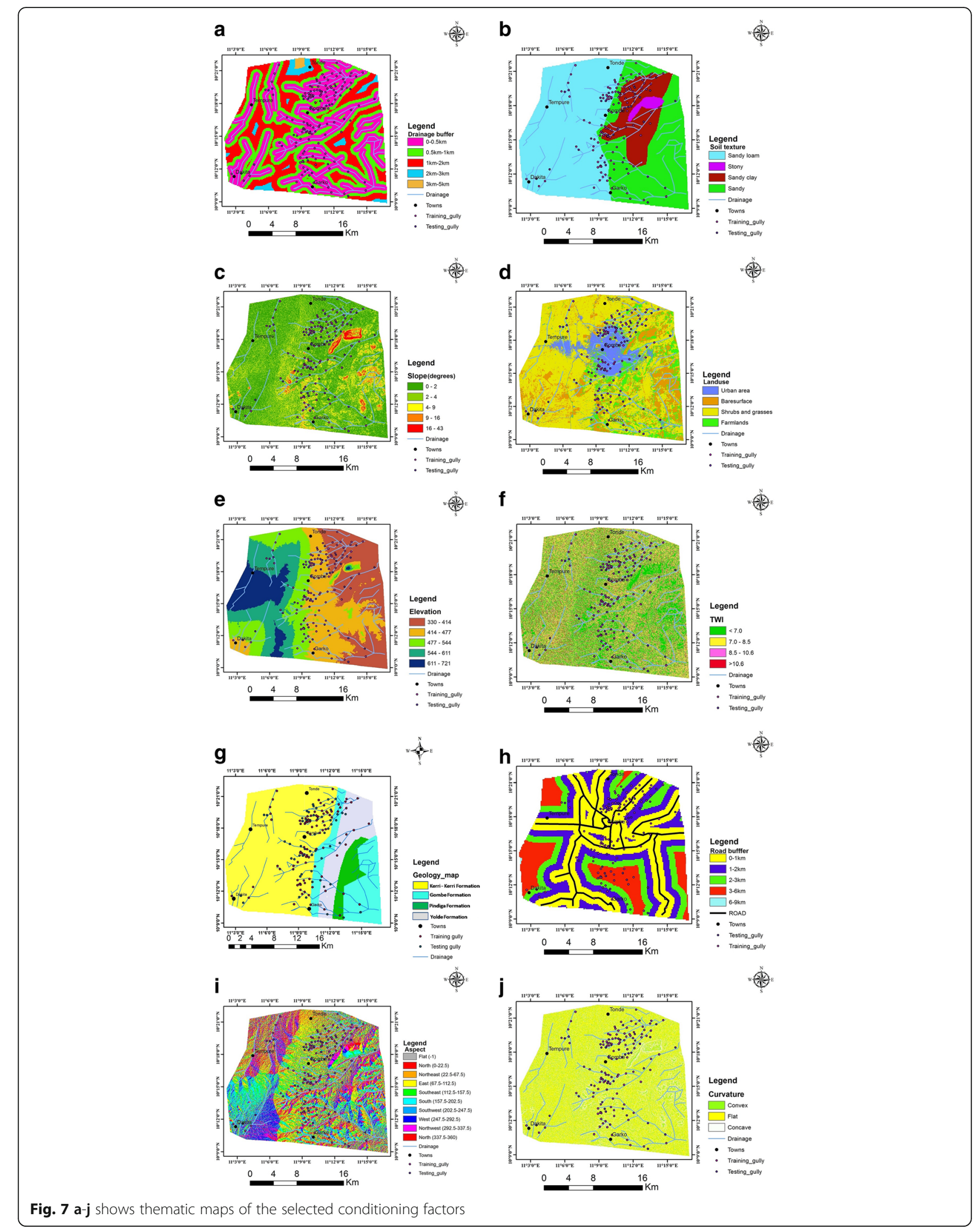




\section{Land use}

Through supervised classification, the landuse map (Fig. 7d) was derived from Landsat $8^{\mathrm{Ts}}$ Main landuse type in the study area include urban area, bare surface, shrubs and grasses, and farmlands. The stability of slope and gully occurrence is influenced by the landuse type (Zakerinejad and Maerker 2015). Infrastructural development such as roads, housing, and industries, prevents infiltration and increases the amount of surface runoff; this runoff concentrates and consequently produces gullies. Generally, bare surfaces and low vegetated areas are gully erosionprone (Gutiérrez et al. 2009).

\section{Elevation}

The type of vegetation and the nature of precipitation are influenced by altitude. DEM was used to obtain the elevation of the area in the ArcGIS environment, five classes were obtained (Fig. 7e): 330 - $414 \mathrm{~m}, 414-477 \mathrm{~m}$, 477 - 544 m, $544-611 \mathrm{~m}, 611-721 \mathrm{~m}$.

\section{TWI}

The topographic wetness index (TWI) which is a secondary topographic factor within the runoff model is usually employed to determine the extent to which topography control hydrological processes. TWI estimates the possibility of water accumulating in soil due to slope and upstream catchment area (Rahmati et al. 2016). Gómez-Gutiérrez et al. (2015), noted that TWI has to be considered in evaluating gully erosion susceptibility. TWI was derived from DEM. The TWI map was divided into four classes (Fig. 7f), they include: $<7,7.0-8.5$, 8.5$10.6,>10.6$.

\section{Lithology}

The lithological properties of the exposed geological formation affect the occurrence of gullies (Golestani et al. 2014). The geology thematic map (Fig. 7g) represents the distribution of the gully erosion within the study area for the underlying lithology. The lithology thematic map was digitized from a geologic map produced by Nigeria Geological Survey Agency (NGSA) and was classified into four, according to the lithologic unit of the area; they include Kerri-Kerri Formation, Gombe Sandstone, Yolde Formation, and Pindiga Formation.

\section{Road buffer}

Paved roads effectively concentrate surface runoff. Road construction and expansion projects tend to encourage slope instability. Five classes of the road buffer map corresponding to buffer distances of $0-1 \mathrm{~km}, 1-2 \mathrm{~km}, 2-3$ km, 3-6 km, 6-9 km (Fig. 7h).

\section{Slope aspect}

The slope aspect has major control over the vegetation type because it influences the duration of sunlight. The slope aspect affects transpiration and moisture content also, evaporation, and indirectly affects the erosion process (Jaafari et al. 2014). Nine classes corresponding to flat, north, northeast, east, southeast, south, southwest, west and northwest are represented in the aspect map (Fig. 7i).

\section{Curvature}

Extensive analysis of profile curvature reveals useful geomorphological information (Davoodi Moghaddam et al. 2015). Three classes of the profile curvature (Fig. 7j) include, convex, flat, and concave.

\section{Results and discussion}

\section{Prediction rate (frequency ratio)}

The prediction rate result shows that drainage buffer, soil texture, slope degree, and landuse, have the major contribution to gully occurrence with a prediction rate of $4.21,3.25,2.49,2.27$, respectively as shown in (Table 3) Others include: elevation (2.03), TWI (1.79), Geology (1.68), Road buffer (1.64), Aspect (1.61), curvature (1).

Table 3 Prediction rate as derived from frequency ratio

\begin{tabular}{llllll}
\hline Conditioning factors & min RF & max RF & (max-min) & min tot. & Prediction rate \\
\hline Profile curvature & 0.27 & 0.45 & 0.18 & 0.18 & 1 \\
Aspect & 0.01 & 0.30 & 0.29 & 0.18 & 0.18 \\
Road buffer & 0 & 0.29 & 0.29 & 0.18 & 1.61 \\
Geology & 0.03 & 0.34 & 0.30 & 0.18 & 1.68 \\
TWI & 0.14 & 0.47 & 0.32 & 0.18 & 1.79 \\
Elevation & 0 & 0.36 & 0.36 & 0.18 & 2.03 \\
Landuse & 0.07 & 0.48 & 0.40 & 0.18 & 2.27 \\
Slope & 0 & 0.44 & 0.44 & 0.18 & 2.49 \\
Soil texture & 0 & 0.58 & 0.58 & 0.18 & 3.25 \\
Drainage buffer & 0 & 0.75 & 0.75 & & 4.21 \\
\hline
\end{tabular}


Table 4 Showing FR values for drainage buffer classes

\begin{tabular}{llllllll}
\hline Factor & Factor class & No. of points & \% of points & class area & \% of class area & Frequency ratio & Relative frequency \\
\hline Drainage buffer & < $500 \mathrm{M}$ & $89,127.17$ & 83.18 & 257,741 & 44.47 & 1.87 & 0.75 \\
& $500 \mathrm{~m}-1 \mathrm{KM}$ & $17,066.91$ & 15.92 & 166,659 & 28.75 & 0.55 & 0.22 \\
& 1KM-2KM & 948.16 & 0.88 & 133,386 & 23.01 & 0.03 & 0.01 \\
& 2KM-3KM & 0 & & 18,938 & 3.26 & 0 & 0 \\
& 3KM-5KM & 0 & & 2859 & 0.49 & 0 & 0 \\
& Sum & $107,142.2$ & 100 & 579,800 & 100 & 2.46 & 1 \\
\hline
\end{tabular}

Interpretation of frequency ratio values for each factor class

The Frequency Ratio correlation value varies between $<1$ to $>1$, when FR value is observed to be less than 1 , it indicates a low correlation between gully location and each class of the predisposing factor, on the other hand, a higher correlation exists if the FR value is observed to be higher than 1 (Poudyal et al. 2010).

Analysis of result obtained from the drainage buffer shows that the 0-500 m class has the highest correlation with FR of (1.87) (Table 4), others include $500 \mathrm{~m}-1 \mathrm{~km}$ (0.553), $1 \mathrm{~km}-2 \mathrm{~km}$ (0.038), therefore it can be deduced that the probability of gully occurrence decreases as the distance from drainage increases.

For the soil texture, the FR value of 2.29, was observed for the sandy clay class while other classes have FR value $<1$ (Table 5). There is a dominance of sand in all classes, which could be attributed to the high erodibility since sand has no cohesion. This finding is in agreement with Mbaya et al. (2012) who stated that the dominance of the sand portion in Nigeria savanna soils has accelerated the occurrence of gully erosion. The high sand content of the soil also indicates that infiltration and percolation are high, thereby bringing about a piping phenomenon and ceiling collapse caused by subsurface flow, this is also in sync with the outcome of work done by Mbaya et al. (2012). The presence of clay in the soil may have contributed to the formation of a gully since clay exhibits shrink and swell characteristics, this could result in the formation of cracks during the alternating warm and dry seasons. These cracks at the first sudden rainfall concentrate the runoff and therefore gully erosion is formed. This is similar to findings by McCloskey et al. (2016).

Assessment of FR for the relationship between slope degree and gully occurrence reveals that slope degree class $0-2^{0}$ is the only class with FR value $>1,(1.25)$, indicating a high correlation. While slope degree greater than 2 all have FR value < 1 (Table 6). Golestani et al. (2014) proved that areas with gentle slope are susceptible to surface flow accumulation and gully erosion.

The landuse variable shows that urban class and farmland class have the FR value $>1(2.39,1.31)$ respectively, while other classes have values less than 1, (Table 7). The high FR value in the urban class could be attributed to the infrastructural development such as roads, housing, industries, which have sealed the ground surface thereby preventing infiltration and increasing the amount of surface runoff, this runoff concentrates consequently forming gullies. This land-use type also deprives the soil of vegetation cover which is supposed to hold the soils together and prevent the direct impact of a raindrop on the soil. The high FR value owned by the farmland class could be attributed to agricultural activities such as plowing, compaction by farm machines and overgrazing, etc. which might have caused the soil to lose its structure and cohesiveness and becomes easily eroded.

Rainfall characteristics and vegetation are influenced by elevation (Gómez-Gutiérrez et al. 2015). The FR value for elevation indicates that altitude between 477 and 544 $(\mathrm{FR}=2.06)$, 544-611 $\mathrm{m}(\mathrm{FR}=1.75)$, and 414-477 $\mathrm{m}(\mathrm{FR}=$ 1.27) possess a strong correlation with gully occurrence (Table 8).

Analysis of the frequency ratio for TWI shows a strong correlation for factor class $>10.6$ and 8.5-10.6, both having FR value $>1$ (Table 9). It can be deduced that classes with high TWI value are pointers to gully occurrence. This result is in agreement with the finding of Rahmati et al. (2016) and Dube et al. (2014).

Assessment of geology shows that the Yolde with units of sandstone and shale and Kerri-Kerri Formation class consisting of sandstone, shale, and clay, have a major contribution with FR value of 1.68 and 1.26 respectively (Table 10). Pindiga formation and Gombe sandstone have FR value $<1$.

Road buffer reveals that Factor class $<1 \mathrm{~km}$ and $1-2 \mathrm{~km}$ have a strong correlation with gully occurrence, with FR value of 1.119 and 1.079. Table 11, while other classes have FR value less than 1 . This suggests that the probability of gully occurrence decreases with distance from the road.

The result from aspect shows that the following classes have a strong relation with gully occurrence: flat face, east, southeast, and north with the following FR values $3.70,1.68,1.20$, and 1.24, Table 12 . Other classes have FR value less than 1 .

Analysis of the profile curvature reveals that the concave class has a major contribution to gully occurrence with FR of 1.45 Table 13. The flat class and convex class have values $<$ 1indicating a very low correlation with FR value of 0.89 and 0.87 respectively. 
Table 5 Showing FR values for soil texture classes

\begin{tabular}{llllllll}
\hline & factor classes & No. of points & \% of points & class area & \% of class area & Frequency ratio & Relative frequency \\
\hline Soil texture & sandy loam & $40,770.94$ & 38.05 & 295,312 & 50.94 & 0.74 & 0.19 \\
& Stony & 0 & 0 & 9047 & 1.56 & 0 & 0 \\
& Sandy clay & $36,030.13$ & 33.62 & 85,107 & 14.68 & 2.29 & 0.58 \\
& Sandy & $30,341.17$ & 28.31 & 190,248 & 32.81 & 0.86 & 0.22 \\
& Sum & $107,142.2$ & 100 & 579,800 & 100 & 3.90 & 1 \\
\hline
\end{tabular}

Table 6 Showing FR values for slope classes

\begin{tabular}{llllllll}
\hline & Factor classes & No. of points & \% of points & Class area & \%of class area & Frequency ratio & Relative frequency \\
\hline Slope & $0-2$ & $65,423.14$ & 61.06 & 283,093 & 48.82 & 1.25 & 0.44 \\
& $2-4$ & $34,133.81$ & 31.85 & 217,715 & 37.54 & 0.84 & 0.30 \\
\\
$4-9$ & 7585.291 & 7.07 & 59,650 & 10.28 & 0.68 & 0.24 \\
& $9-16$ & 0 & 0 & 14,653 & 2.52 & 0 & 0 \\
\\
$16-43$ & 0 & 0 & 4708 & 0.81 & 0 & 0 \\
Sum & $107,142.2$ & 100 & 579,819 & 100 & 2.78 & 1 \\
\hline
\end{tabular}

Table 7 Showing FR values for landuse classes

\begin{tabular}{llllllll}
\hline & factor classes & No. of points & \% of points & class area & \% of class area & Frequency ratio & Relative frequency \\
\hline Landuse & Urban area & 29,393 & 27.43 & 66,507 & 11.47 & 2.39 & 0.48 \\
& BARESURFACE & 7585.291 & 7.07 & 110,674 & 19.08 & 0.37 & 0.07 \\
& SHRUBS \& GRASSES & $51,200.72$ & 47.78 & 324,531 & 55.97 & 0.85 & 0.17 \\
& FARMLANDS & $18,963.23$ & 17.69 & 78,107 & 13.47 & 1.31 & 0.26 \\
& Sum & $107,142.2$ & 100 & 579,819 & 100 & 4.93 & 1 \\
\hline
\end{tabular}

Table 8 Showing FR values for elevation classes

\begin{tabular}{llllllll}
\hline & factor classes & No. of points & \% of points & class area & \% of class area & Frequency ratio & Relative frequency \\
\hline Elevation & $330-414 \mathrm{~m}$ & $28,444.84$ & 26.54 & 149,566 & 48.82 & 0.54 & 0.09 \\
& $414-477 \mathrm{~m}$ & $51,200.72$ & 47.78 & 156,698 & 37.54 & 1.27 & 0.22 \\
& $477-544 \mathrm{~m}$ & $22,755.87$ & 21.23 & 104,788 & 10.28 & 2.06 & 0.36 \\
& $544-611 \mathrm{~m}$ & 4740.807 & 4.42 & 105,167 & 2.52 & 1.75 & 0.31 \\
& $611-721 \mathrm{~m}$ & 0 & 0 & 63,600 & 0.81 & 0 & 0 \\
& Sum & $107,142.2$ & 100 & 579,819 & 100 & 5.63 & 1 \\
\hline
\end{tabular}

Table 9 Showing FR values for TWI classes

\begin{tabular}{llllllll}
\hline & factor classes & No. of points & \% of points & class area & \% of class area & Frequency ratio & Relative frequency \\
\hline TWI & $<7.0$ & $36,030.13$ & 33.62 & 250,191 & 43.14 & 0.77 & 0.14 \\
& $7.0-8.5$ & $38,874.62$ & 36.28 & 213,435 & 36.81 & 0.98 & 0.18 \\
& $8.5-10.6$ & $15,170.58$ & 14.15 & 79,075 & 13.63 & 1.03 & 0.19 \\
$>$ >10.6 & $17,066.91$ & 15.92 & 37,118 & 6.40 & 2.48 & 0.47 \\
Sum & $107,142.2$ & 100 & 579,819 & 100 & 5.29 & 1 \\
\hline
\end{tabular}


Table 10 Showing FR values for geology classes

\begin{tabular}{llllllll}
\hline & factor classes & No. of points & \% of points & class area & \% of class area & Frequency ratio & Relative frequency \\
\hline Geology & kerri kerri form & $81,541.88$ & 76.10 & 349,006 & 60.20 & 1.26 & 0.34 \\
& Gombe sandstone & $12,326.1$ & 11.50 & 111,965 & 19.31 & 0.59 & 0.16 \\
& Yolde formation & $12,326.098$ & 11.50 & 83,748 & 14.44 & 1.68 & 0.45 \\
& Pindiga formation & 948.1614 & 0.88 & 35,002 & 6.03 & 0.14 & 0.03 \\
& sum & $107,142.2$ & 100 & 579,721 & 100 & 3.69 & 1 \\
\hline
\end{tabular}

Table 11 Showing FR values for road buffer classes

\begin{tabular}{llllllll}
\hline & factor classes & No. of points & \% of points & class area & \% of class area & Frequency ratio & Relative frequency \\
\hline Road buffer & >1KM & $50,252.56$ & 46.90 & 242,971 & 41.88 & 1.11 & 0.29 \\
& 1-2KM & 29,393 & 27.43 & 147,361 & 25.40 & 1.07 & 0.28 \\
& 2-3KM & $14,222.42$ & 13.27 & 97,078 & 16.73 & 0.79 & 0.21 \\
& 3-6KM & $13,274.26$ & 12.38 & 92,341 & 15.92 & 0.77 & 0.20 \\
& 6-9KM & 0 & 0 & 275 & 0.04 & 0 & 0 \\
& sum & $107,142.2$ & 100 & 580,026 & 100 & 3.77 & 1 \\
\hline
\end{tabular}

Table 12 Showing FR values for aspect classes

\begin{tabular}{llllllll}
\hline & factor classes & No. of points & \% of points & class area & \% of class area & Frequency ratio & Relative frequency \\
\hline Aspect & Flat & 1896.323 & 1.76 & 2770 & 0.47 & 3.70 & 0.30 \\
& North & 6637.13 & 6.19 & 44,532 & 7.68 & 0.80 & 0.06 \\
& North East & $14,222.42$ & 13.27 & 85,699 & 14.78 & 0.89 & 0.07 \\
& East & 29,393 & 27.43 & 94,206 & 16.24 & 1.68 & 0.13 \\
& South East & $19,911.39$ & 18.58 & 89,357 & 15.41 & 1.20 & 0.09 \\
& South & $12,326.1$ & 11.50 & 68,307 & 11.78 & 0.97 & 0.08 \\
South West & 5688.969 & 5.30 & 51,571 & 8.89 & 0.59 & 0.04 \\
& West & 1896.323 & 1.76 & 52,901 & 9.12 & 0.19 & 0.01 \\
& North West & 8533.453 & 7.96 & 61,720 & 10.64 & 0.74 & 0.06 \\
North & 6637.13 & 6.19 & 28,756 & 4.95 & 1.24 & 0.10 \\
\hline
\end{tabular}

Table 13 Showing FR values for curvature

\begin{tabular}{llllllll}
\hline Factor & factor classes & No. of points & \% of points & class area & \% of class area & Frequency ratio & Relative frequency \\
\hline Curvature & Convex & $17,066.91$ & 15.92 & 105,704 & 18.23 & 0.87 & 0.27 \\
& Flat & $59,734.17$ & 55.75 & 361,217 & 62.29 & 0.89 & 0.27 \\
& Concave & $30,341.17$ & 28.31 & 112,898 & 19.47 & 1.45 & 0.45 \\
& Sum & $107,142.2$ & 100 & 579,819 & 100 & 3.22 & 1 \\
\hline
\end{tabular}


Table 14 Final criteria weights of factors from AHP

\begin{tabular}{lll}
\hline Variables & Criteria weight & Integer weight \\
\hline TWI & 0.047 & 4.77 \\
Elevation & 0.050 & 5.00 \\
Aspect & 0.054 & 5.49 \\
Road buffer & 0.070 & 7.04 \\
Curvature & 0.072 & 7.26 \\
Slope & 0.075 & 7.58 \\
Land cover & 0.096 & 9.61 \\
Geology & 0.152 & 15.24 \\
Soil & 0.180 & 18.08 \\
drainage buffer & 0.198 & 19.887
\end{tabular}

Analytical hierarchy process (AHP)

The result of the AHP pairwise comparison shows that drainage buffer, soil texture, geology, and landcover have the highest contribution to gully formation with criteria weight $0.19,0.18,0.15,0.09$, respectively, others include slope (0.07), curvature (0.072), road buffer (0.0704), aspect $(0.054)$ elevation $(0.050)$, TWI $(0.047)$ having the lowest impact on gully erosion respectively. (Table 14) and (Table 15).

\section{Gully susceptibility maps}

The respective weights from the Frequency ratio and AHP were multiplied by each predisposing factor map. This method was employed to produce the area's gully erosion susceptibility index map. The GESM shows a range of susceptibility to the study area. The produced susceptibility index maps for the frequency ratio and AHP models were reclassified into four zones according to the quantile classification scheme (Fig. 8a and b). That is low, medium, high, and very high susceptibility zones (Youssef et al. 2015).

\section{Validation}

\section{Gully density distribution}

Prediction rate curves coupled with gully density distribution within the susceptible areas were employed to check for the validity of the susceptibility map. Gully erosion density distribution for frequency ratio and AHP reveals that gullies are concentrated in the very high susceptibility class and it decreases as it gets to the low susceptibility class, density values for FR include: $0.729,0.223,0.097$, 0.005 (Table 16), and AHP include: 0.74,10.23, 0.10, 0.006

Table 15 AHP comparison matrix for the conditioning factors

\begin{tabular}{|c|c|c|c|c|c|c|c|c|c|c|}
\hline \multirow[b]{2}{*}{ Predictors } & \multirow[b]{2}{*}{ Aspect } & \multicolumn{2}{|l|}{ AHP Matrix } & \multirow[b]{2}{*}{ Drainage buffer } & \multirow[b]{2}{*}{ Landcover } & \multirow[b]{2}{*}{ Slope } & \multirow[b]{2}{*}{ Geology } & \multirow[b]{2}{*}{ Curvature } & \multirow[b]{2}{*}{ Elevation } & \multirow[b]{2}{*}{ Soil } \\
\hline & & Road buffer & TWI & & & & & & & \\
\hline Aspect & 1 & 1 & 1 & $1 / 3$ & $1 / 2$ & $1 / 2$ & $1 / 3$ & 1 & 2 & $1 / 4$ \\
\hline Road buffer & 1 & 1 & 2 & $1 / 3$ & $1 / 2$ & 1 & $1 / 2$ & 1 & 3 & $1 / 3$ \\
\hline TWI & 1 & $1 / 2$ & 1 & $1 / 4$ & $1 / 2$ & $1 / 2$ & $1 / 3$ & 1 & 1 & $1 / 3$ \\
\hline drainage buffer & 3 & 3 & 4 & 1 & 2 & 3 & 2 & 3 & 5 & 1 \\
\hline Land cover & 2 & 2 & 2 & $1 / 2$ & 1 & 2 & $1 / 2$ & $1 / 2$ & 3 & $1 / 2$ \\
\hline Slope & 2 & 1 & 2 & $1 / 3$ & $1 / 2$ & 1 & $1 / 2$ & 1 & 3 & $1 / 3$ \\
\hline Geology & 3 & 2 & 3 & $1 / 2$ & 2 & 2 & 1 & 3 & 4 & 1 \\
\hline Curvature & 1 & 1 & 1 & $1 / 3$ & 2 & 1 & $1 / 3$ & 1 & 2 & $1 / 3$ \\
\hline Elevation & $1 / 2$ & $1 / 3$ & 1 & $1 / 5$ & $1 / 3$ & 3 & $1 / 4$ & $1 / 2$ & 1 & $1 / 4$ \\
\hline Soil & 4 & 3 & 3 & 1 & 2 & 3 & 1 & 3 & 4 & 1 \\
\hline Sum & 18.50 & 14.83 & 20.00 & 4.78 & 11.33 & 17.00 & 6.75 & 15.00 & 28.00 & 5.33 \\
\hline
\end{tabular}




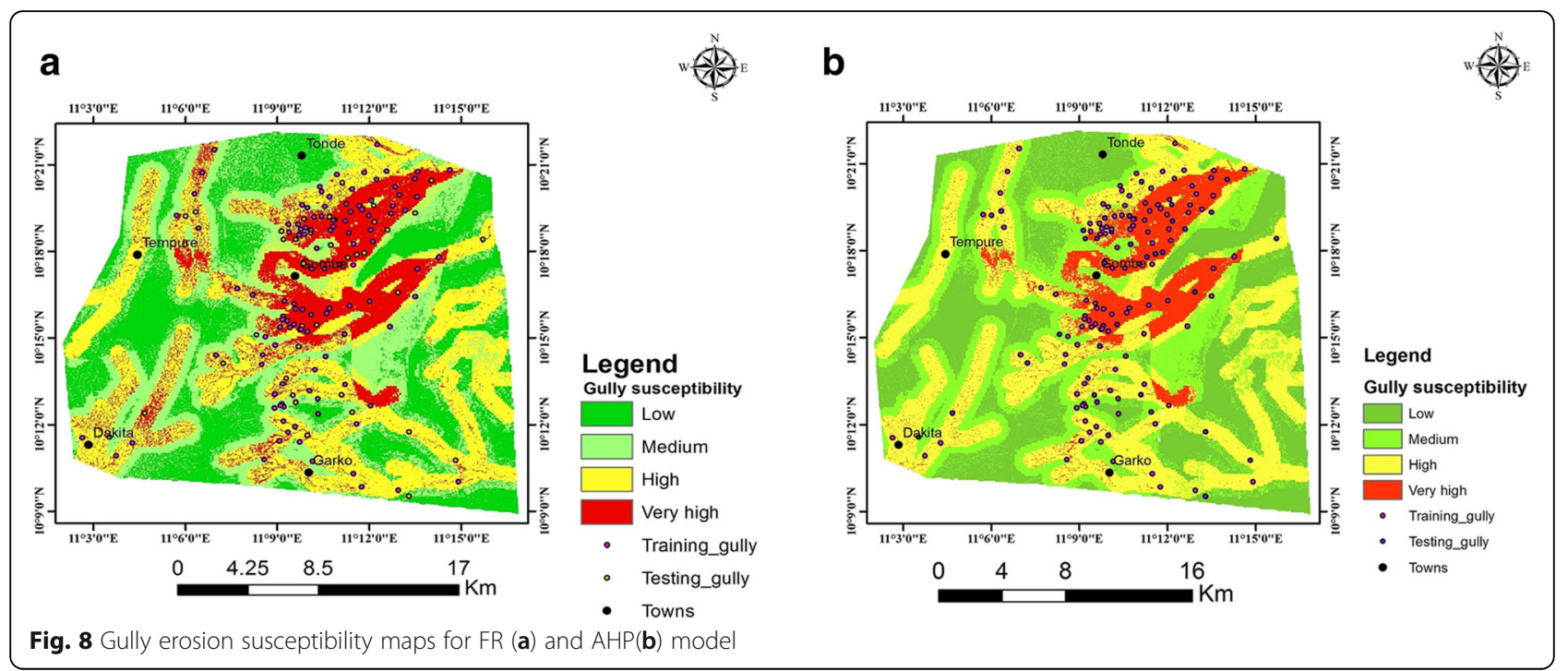

(Table 17). Gupta et al. (2008) stated in his work that the distribution of density decreases from the high susceptibility class to low class, which is in agreement with this study.

\section{The area under the curve (AUC)}

To determine the accuracy of the Frequency ratio and AHP model applied, the (AUC) area under the curve was employed (Mohammady et al. 2012); AUC analysis is an efficient technique for evaluating the correctness of a test (Razandi et al. 2015). This curve indicates the accuracy and reliability of a predicting system. Rahmati et al. (2016) classified the AUC values as: 0.5-0.6, poor; $0.6-0.7$, average; $0.7-0.8$, good; $0.8-0.9$, very good; and 0.9-1, excellent. For this study, the FR and AHP model gave AUC values of 0.73 and 0.72 respectively (Fig. 9). The outcome indicates that both models have high prediction accuracy with the Frequency ratio model slightly higher than the AHP model. Therefore the GESM produced using these models in this study area is reliable and can be used for land management and future planning.

\section{Conclusion}

It is important to identify areas susceptible to gully erosion and to generate susceptibility maps. A comprehensive and dependable gully inventory map was successfully developed through detailed field surveys and from high-resolution Google Earth imagery. The spatial relationship between gully occurrences and its ten carefully selected causative factors which include: drainage buffer, soil texture, slope degree, land use, elevation, TWI, Lithology, Road buffer, and aspect were assessed using FR and AHP model, the FR model revealed that drainage buffer, soil texture, slope degree, and landuse, have the major contribution to gully occurrence and according to AHP model drainage buffer, soil texture, geology, and landcover are the most important contributors. These two methods were employed to generate two gully erosion susceptibility maps (GESM) for the study area. The GESM shows a range of susceptibility in the study area. The gully erosion susceptibility index maps generated from the FR and AHP models were reclassified into four zones according to the quantile classification scheme.

Table 16 Gully density distribution for FR

\begin{tabular}{llllll}
\hline Class & area $\left(\mathbf{m}^{\mathbf{2}}\right)$ & \%(class) & class area $\left.\mathbf{( k m}^{\mathbf{2}}\right)$ & gully area $(\mathbf{k m})$ & Gully density \\
\hline Low & 165,010 & 28.67121 & 0.16501 & 0.0009 & 0.005 \\
Medium & 146,509 & 25.45658 & 0.146509 & 0.014 & 0.097 \\
High & 199,041 & 34.58425 & 0.199041 & 0.044 & 0.223 \\
Very high & 64,965 & 11.28795 & 0.064965 & 0.047 & 0.729 \\
\hline
\end{tabular}


Table 17 Gully density distribution for AHP

\begin{tabular}{llllll}
\hline Class & $\begin{array}{l}\text { area } \\
\left(\mathbf{m}^{\mathbf{2}}\right)\end{array}$ & \%(class) & $\begin{array}{l}\text { gully area } \\
\left(\mathbf{k m}^{\mathbf{2}}\right)\end{array}$ & $\begin{array}{l}\text { gully area } \\
\left(\mathbf{k m}^{\mathbf{2}}\right)\end{array}$ & $\begin{array}{l}\text { gully } \\
\text { density }\end{array}$ \\
\hline Low & 155,010 & 28.46 & 0.15501 & 0.0009 & 0.006 \\
Medium & 136,509 & 25.06 & 0.136509 & 0.014 & 0.104 \\
High & 189,041 & 34.71 & 0.189041 & 0.044 & 0.235 \\
$\begin{array}{l}\text { Very } \\
\text { high }\end{array}$ & 63,965 & 11.74 & 0.063965 & 0.047 & 0.741 \\
\hline
\end{tabular}

The performances of the models were subsequently validated using the AUC plot and gully density distribution. AUC values of 0.73 and 0.72 were obtained for FR and AHP models respectively. The obtained values indicated that both models have high prediction accuracy, though that of the FR is slightly higher than AHP. In addition to the AUC, the gully erosion density distribution for both methods revealed that gullies are concentrated in the very high susceptibility class and it decreases as it gets to the low susceptibility class, this outcome is as expected. The high accuracy obtained from AUC plots coupled with the alignment of the gully density distribution with the varying susceptibility classes proves that the GESM produced is reliable and accurate. The GESM produced shall be of enormous importance for town planners and decisionmakers when there is a need for future infrastructural developments.

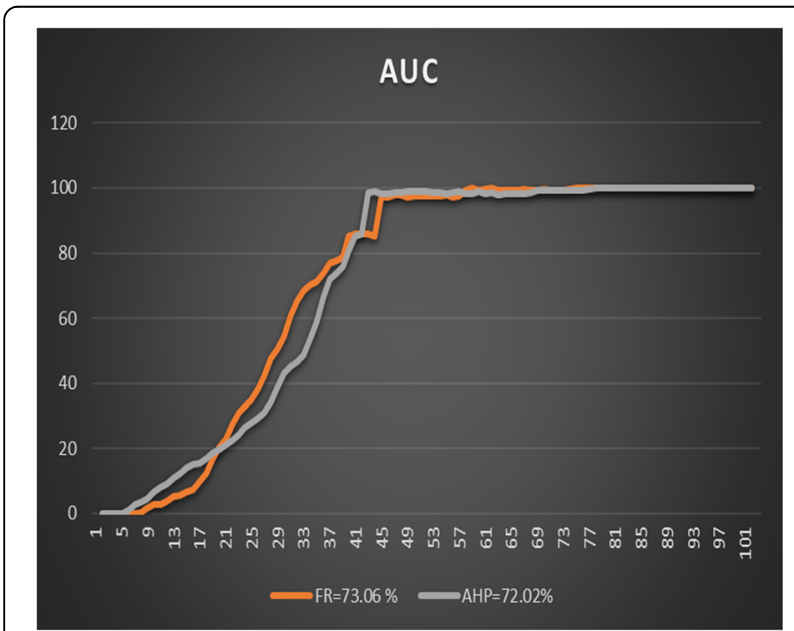

Fig. 9 Area under curve plot showing the predictive capacity of the two models

\section{Abbreviations}

AUC: Area Under Curve; AHP: Analytical Hierarchy Process; FR: Frequency Ratio; GESM: Gully Erosion Susceptibility Map; TWI: Topographic Wetness Index; DEM: Digital Elevation Model; NGSA: Nigeria Geological Survey Agency

\section{Acknowledgments}

Thanks to staff and students of the Geology Department, University of Nigeria Nsukka.

\section{Authors' contributions}

Ol was involved in the field exercise and contributed to every step of the modeling and was a major contributor in writing the manuscript. UIJ was involved in the field exercise and produced the conditioning factor maps, he was also a major contributor in writing the manuscript. OS was involved in the field exercise and tested the models using AUC, gully density distribution and contributed towards writing the manuscript. OO generated the susceptibility index map from the FR and AHP models, he was a major contributor in writing the manuscript. The authors read and approved the final manuscript.

\section{Funding}

This project was funded by the authors.

\section{Availability of data and materials}

The datasets used and/or analyzed during the current study are available from the corresponding author on reasonable request.

\section{Competing interests}

The authors declare that they have no competing interests.

Received: 21 May 2020 Accepted: 6 October 2020

Published online: 23 November 2020

\section{References}

Abedini M, Ghasemyan B, Mogaddam MR (2017) Landslide susceptibility mapping in Bijar city, Kurdistan Province, Iran: a comparative study by logistic regression and AHP models. Environ Earth Sci 76(8):308

Abubakar MB, Dike EFC, Obaje NG, Wehner H, Jauro A (2008) Petroleum prospectivity of cretaceous formations in the Gongola Basin, upper Benue trough, Nigeria: an organic geochemical perspective on a migrated oil controversy. J Pet Geol 31(4):387-407

Arabameri A, Rezaei K, Pourghasemi HR, Lee S, Yamani M (2018) GIS-based gully erosion susceptibility mapping: a comparison among three data-driven models and AHP knowledge-based technique. Environ Earth Sci 77(17):628

Arabi AS, Nur A, Dewu BBM (2009) Hydro geo-electrical investigation in Gombe town and environs, northeastern Nigeria. J Appl Sci Environ Manag 13(3)

Bathrellos GD, Skilodimou HD, Chousianitis K, Youssef AM, Pradhan B (2017) Suitability estimation for urban development using multi-hazard assessment map. Sci Total Environ 575:119-134

Chaplot V, Giboire G, Marchand P, Valentin C (2005) Dynamic modelling for linear erosion initiation and development under climate and land-use changes in northern Laos. Catena 63(2-3):318-328

Chung CJF, Fabbri AG (2003) Validation of spatial prediction models for landslide hazard mapping. Nat Hazards 30(3):451-472

Conforti M, Aucelli PP, Robustelli G, Scarciglia F (2011) Geomorphology and GIS analysis for mapping gully erosion susceptibility in the Turbolo stream catchment (northern Calabria, Italy). Nat Hazards 56(3):881-898

Conoscenti C, Agnesi V, Angileri S, Cappadonia C, Rotigliano E, Märker M (2013) A GIS-based approach for gully erosion susceptibility modelling: a test in Sicily, Italy. Environ Earth Sci 70(3):1179-1195

Conoscenti C, Angileri S, Cappadonia C, Rotigliano E, Agnesi V, Märker M (2014) Gully erosion susceptibility assessment by means of GIS-based logistic regression: a case of Sicily (Italy). Geomorphology 204:399-411

Conoscenti C, Di Maggio C, Rotigliano E (2008) GIS analysis to assess landslide susceptibility in a fluvial basin of NW Sicily (Italy). Geomorphology 94(3-4): 325-339

Dube F, Nhapi I, Murwira A, Gumindoga W, Goldin J, Mashauri DA (2014) Potential of weight of evidence modeling for gully erosion hazard assessment in Mbire District-Zimbabwe. Phys Chem Earth, Parts A/B/C 67: 145-152 
Ghorbani Nejad S, Falah F, Daneshfar M, Haghizadeh A, Rahmati O (2017) Delineation of groundwater potential zones using remote sensing and GISbased data-driven models. Geocarto Int 32(2):167-187

Golestani G, Issazadeh L, Serajamani R (2014) Lithology effects on gully erosion in Ghoorichay watershed using RS \& GIS. Int J Biosci 4(2):71-76

Gómez-Gutiérrez Á, Conoscenti C, Angileri SE, Rotigliano E, Schnabel S (2015) Using topographical attributes to evaluate gully erosion proneness (susceptibility) in two mediterranean basins: advantages and limitations. Nat Hazards 79(1):291-314

Gupta RP, Kanungo DP, Arora MK, Sarkar S (2008) Approaches for comparative evaluation of raster GIS-basedlandslide susceptibility zonation maps. Int J Appl Earth Obs Geoinf 10:330-341. https://doi.org/10.1016/j.jag.2008.01.003

Gutiérrez ÁG, Schnabel S, Contador FL (2009) Gully erosion, land use and topographical thresholds during the last 60 years in a small rangeland catchment in SW Spain. Land Degrad Dev 20(5):535-550

Guzzetti F (2002) Landslide hazard assessment and risk evaluation: Limits and prospectives. In Proceedings 4th Plinius Conference on Mediterranean Storms. Universitat de Illes Baleares, Mallorca, Spain.

Jaafari A, Najafi A, Pourghasemi HR, Rezaeian J, Sattarian A (2014) GIS-based frequency ratio and index of entropy models for landslide susceptibility assessment in the Caspian forest, northern Iran. Int J Environ Sci Technol 11(4):909-926

Kirkby MJ, Bracken LJ (2009) Gully processes and gully dynamics. Earth Surface Processes Landforms: J Br Geomorphological Res Group 34(14):1841-1851

Lee S, Talib JA (2005) Probabilistic landslide susceptibility and factor effect analysis. Environ Geol 47(7):982-990

Ligonja PJ, Shrestha RP (2015) Soil erosion assessment in kondoa eroded area in Tanzania using universal soil loss equation, geographic information systems and socioeconomic approach. Land Degrad Dev 26(4):367-379

Magliulo P (2012) Assessing the susceptibility to water-induced soil erosion using a geomorphological, bivariate statistics-based approach. Environ Earth Sci 67(6):1801-1820

Mbaya LA (2017) Spatial analysis of gully erosion control measures in Gombe town, Gombe state Nigeria. Adv Image Video Process 5(4):17-17

Mbaya LA, Ayuba HK, Abdullahi J (2012) An assessment of gully erosion in Gombe town, Gombe state, Nigeria. J Geogr Geol 4(3):110

McCloskey GL, Wasson RJ, Boggs GS, Douglas M (2016) Timing and causes of gully erosion in the riparian zone of the semi-arid tropical Victoria River, Australia: management implications. Geomorphology 266:96-104

Moghaddam DD, Rezaei M, Pourghasemi HR, Pourtaghie ZS, Pradhan B (2015) Groundwater spring potential mapping using bivariate statistical model and GIS in the Taleghan watershed, Iran. Arab J Geosci 8(2):913-929

Mohammady M, Pourghasemi HR, Pradhan B (2012) Landslide susceptibility mapping at Golestan Province, Iran: a comparison between frequency ratio, Dempster-Shafer, and weights-of-evidence models. J Asian Earth Sci 61:22136.

Nampak H, Pradhan B, Mojaddadi Rizeei H, Park HJ (2018) Assessment of land cover and land use change impact on soil loss in a tropical catchment by using multitemporal SPOT-5 satellite images and revised universal soil loss equation model. Land Degrad Dev 29(10):3440-3455

Orazulike DM (1988) Hazardous earth processes in parts of Bauchi State, Nigeria: Their causes and environmental implications. Nat Hazards 1(2):155-60.

Ouyang C, Zhou K, Xu Q, Yin J, Peng D, Wang D, Li W (2017) Dynamic analysis and numerical modeling of the 2015 catastrophic landslide of the construction waste landfill at Guangming, Shenzhen, China. Landslides 14(2): $705-718$

Ozioko OH, Igwe O (2020) GlS-based landslide susceptibility mapping using heuristic and bivariate statistical methods for Iva Valley and environs Southeast Nigeria. Environ Monit Assess 192(2):1-19

Papadakis M, Karimalis A (2017) Producing a landslide susceptibility map through the use of analytic hierarchical process in finikas watershed, North Peloponnese, Greece. Am J Geogr Inf Syst 6(1A):14-22

Poesen J, Nachtergaele J, Verstraeten G, Valentin C (2003) Gully erosion and environmental change: importance and research needs. Catena 50(2-4):91133

Poudyal CP, Chang C, Oh HJ, Lee S (2010) Landslide susceptibility maps comparing frequency ratio and artificial neural networks: a case study from the Nepal Himalaya. Environ Earth Sci 61(5):1049-1064

Rahmati O, Pourghasemi HR, Melesse AM (2016) Application of GIS-based data driven random forest and maximum entropy models for groundwater potential mapping: a case study at Mehran region, Iran. Catena 137:360-372
Rahmati O, Samani AN, Mahdavi M, Pourghasemi HR, Zeinivand H (2015) Groundwater potential mapping at Kurdistan region of Iran using analytic hierarchy process and GIS. Arab J Geosci 8(9):7059-7071

Razandi Y, Pourghasemi HR, Neisani NS, Rahmati O (2015) Application of analytical hierarchy process, frequency ratio, and certainty factor models for groundwater potential mapping using GIS. Earth Sci Inf 8(4):867-883

Rizeei HM, Saharkhiz MA, Pradhan B, Ahmad N (2016) Soil erosion prediction based on land cover dynamics at the Semenyih watershed in Malaysia using LTM and USLE models. Geocarto Int 31(10):1158-1177

Saaty TL (1980) The analytical hierarchy process. Priority setting. MacGraw-Hill: Resource Allocation, New York International Book Company, p 287

Tian Y, Xu C, Chen J, Hong H (2017) Spatial distribution and susceptibility analyses of pre-earthquake and coseismic landslides related to the Ms 6.5 earthquake of 2014 in Ludian, Yunan, China. Geocarto Int 32(9):978-989

Torri D, Borselli L, Gariano SL, Greco R, laquinta P, lovine G et al (2012) Identifying gullies in the Mediterranean environment by coupling a complex threshold model and a GIS. RENDICONTI Online dellaSocietàGeologicaltaliana 89(PART 1):441-443

Xia D, Deng Y, Wang S, Ding S, Cai C (2015) Fractal features of soil particle-size distribution of different weathering profiles of the collapsing gullies in the hilly granitic region, South China. Nat Hazards 79(1):455-478

Youssef AM, Pradhan B, Jebur MN, El-Harbi, HM (2015) Landslide susceptibility mapping using ensemble bivariate and multivariate statistical models in Fayfa area, Saudi Arabia. Environ Earth Sci. 73(7):3745-761

Zaborski P, Ugodulunwa F, Idornigie A, Nnabo P, Ibe K (1997) Stratigraphy and structure of the cretaceous Gongola Basin, Northeast Nigeria. Bull des Centres de Recherches Explor-Prod Elf Aquitaine 21(1):153-185

Zakerinejad R, Maerker M (2015) An integrated assessment of soil erosion dynamics with special emphasis on gully erosion in the Mazayjan basin, southwestern Iran. Nat Hazards 79(1):25-50

\section{Publisher's Note}

Springer Nature remains neutral with regard to jurisdictional claims in published maps and institutional affiliations.

\section{Submit your manuscript to a SpringerOpen ${ }^{\circ}$ journal and benefit from:}

- Convenient online submission

- Rigorous peer review

- Open access: articles freely available online

- High visibility within the field

- Retaining the copyright to your article

Submit your next manuscript at $>$ springeropen.com 